\title{
Lunar rhythms in agriculture - review on scientific perspectives
}

\begin{abstract}
An attempt is made to review the salient research findings of the application of astronomical ephemeris in agriculture. In biodynamic agriculture, lunar rhythms are used as a calendar for scheduling farming operations like tilling, planting and harvesting of crops. Studies reveal seed germination, growth and production of crops are appraised due to the lunar influences. The scientific understanding of rhythms and its reflection through 12 zodiac signs are evident in multiple germination studies, growth and yield analysis on crops. Since these are non-monitoring inputs, more insights into rhythms and their physiological response that results in high-end physiological and biochemical characterization of various parts of plant is warranted. Planting based on the lunar cycles is an important component of biodynamic agriculture. Though several subjective insights are shared by the farmers there is a need for region-specific scientific studies to evaluate those experiences objectively. Compared to studies on biodynamic preparations, manures and their effect on crop, few studies on planting by moon rhythms are reported under field condition. Planting in sync with lunar rhythms is a zero-cost input for the farmers to take advantage for enhancing crop production and simultaneously improve the quality of byproducts
\end{abstract}

Keywords: biodynamic agriculture, planting calendar, lunar rhythms
Volume 14 Issue 2 - 202 I

\author{
Jayachandran Sivasankari,' Appachanda \\ Thimmaiah ${ }^{2}$ \\ 'Researcher, 2।3। Spalding Forest Court, USA \\ ${ }^{2}$ Chief scientific officer, Spades SBC, USA.
}

\section{Correspondence: Appachanda Thimmaiah, Chief Scientific officer, Spades SBC, Minneapolis, MN. USA,}

Email thimmaiah@regenerative-agriculture.net

Received: March 15, 2021 | Published: April 19, 2021

\section{Abbreviations: $\mathrm{BD}$, biodynamic}

\section{Introduction}

The current conventional systems of agriculture need a radical shift to a more gentle and resilient system of agriculture that could meet the needs of the growing population and simultaneously restore the ecosystems. Among the different systems of ecological agriculture, biodynamic agriculture is regenerative in its approach and focuses on utilization of natural resources for self-sufficiency of all farm inputs. ${ }^{1}$ However, use of organic farm inputs (monitoring resources) has many challenges such as germination of seeds, nematodes, insect pests and disease incidences encountered during cropping and resultant reduction in yields. ${ }^{2}$ It is a well-known fact that moisture content is an inevitable factor from seed germination to harvest including pest and disease management during the crop cycle. Moisture, moon's phase and its relation to gravitational forces are directly reflected in development of life forms. ${ }^{3}$ Every fraction of the earth is subjected to the changes that are based on the positions of earth, moon, and sun. Scientific studies reveal that more than six hundred organisms have links to lunar rhythms either in their reproductive cycles or in their feeding habits. ${ }^{4}$ Some studies have reported that the moon appears to exhibit tidal effects on groundwater tables, ${ }^{5}$ creating more moisture in the soil at the time of new and full moon days. ${ }^{4}$ This moisture encourages the germination rate and plant metabolism. Schad ${ }^{4}$ and Spiss $^{6}$ reported extensive studies of several investigators and their own scientific experiments on different crops: rye, carrot, potato, radish and bean. ${ }^{8}$ In their review summaries, the effect of the lunar phase or tidal cycles highly influenced the seed germination and plant metabolism for example, oxygen consumption of potato and carrot, osmotic-diffusion potential of bean, nutrients uptake \& growth rate of Sudan grass, corn and wild plants. Likewise, the fluctuations in the diameter of tree trunks and wood properties are also observed according to the moon rhythms. ${ }^{9}$

The moonlight affects the photoperiodism of plants, the intensity of a full moon can influence time measurements. Due to specific photoperiodic phenomena of short-day plants (long night plants), the intensity of moonlight might promote the number of flowers in short day plants. ${ }^{10}$ Planning agronomical practices based on moon phases and astrological signs produces better crops and yield. ${ }^{11}$ The method of following almanac for crop production is known as agriculture astronomy/lunar farming. This folklore tradition was widely followed by ancient Romans and Greeks in farming. ${ }^{1}$. It is reported that several parts of Asian region also followed this lore. According to this traditional wisdom, crops are planted during the waxing period, it was believed that as the moon grows, so too will the plants. Conversely, harvesting is undertaken during the waning moon. Variations were allowed, depending on the nature of the end-product. ${ }^{13}$ This practice remains popular among biodynamic farmers by utilizing lunar rhythms as a tool for scheduling the farm activities. ${ }^{11-14}$

Biodynamic (BD) Agriculture is the oldest form of ecological agriculture with a history of more than 95 years that is based on the anthroposophical concepts of Rudolf Steiner. ${ }^{15-18}$ This system of farming follows planting almanac and utilizes specific fermented herbal preparations as field sprays. The preparations used are called cow horn manure (BD 500), cow horn silica (BD 501), six compost additives numbered from BD 502 to BD 507. In addition, biodynamic system of agriculture follows the common agronomical practices like crop rotation and using various organic amendments ${ }^{15,19,20,21-23}$ The concept of $\mathrm{BD}$ agriculture and organizations that promote them has spread around the world and is widely practiced in cool and warm climates in all continents. ${ }^{24}$ Nevertheless, attention has been increasing in different continents, such as Asia and Africa ${ }^{25,26}$ The application of BD preparations in the fields enhances the soil fertility and plant resilience to pests and diseases. ${ }^{28-30}$ Demeter International is a network of individual certification organizations around the world headquartered in Germany. According to the Demeter-International ${ }^{27}$, an area of 208,327 ha and 6,396 farms across 62 countries (Demeter operation of a total of member countries) are farmed under biodynamic practices. 
In this review, an attempt has been made to appraise the salient research findings on the use of planting calendar for seed germination, crop growth and yield of crops.

\section{Scientific studies on planting calendar}

Planting by the moon rhythms is an ancient practice utilized to pre plan farm operations by taking advantage of the natural rhythms to support crop health and production. This is as much an oldtime method highly encouraged by Rudolf Steiner ${ }^{1}$ as a part of BD agriculture. Steiner emphasized researchers to study the relationship of lunar rhythms and plant growth through scientific research.

\section{Lunar rhythms}

In biodynamic agriculture, the farming operations are synchronized with the lunar rhythms. There are 6 different moon cycles (or rhythms) that recur on approximately every 27 to 29.5 days. The six moon rhythms such as 1 . New moon to full moon, 2. Ascending-descending moon, 3. Moon opposite to Saturn, 4. Moon nodes, 5. Apogee -perigee 6. Moon in Zodiac constellation. This is explained elaborately below.

Table I Tabulation of lunar cycle and significance in farm operation
Generally, it begins at a new moon (moon is invisible, because it is closer to the sun) and the moon moves away from the sun where it reaches the second quarter (moon's disc is half bright, half dark). This is followed by a full moon which is about 12 times as bright as the first quarter, then comes the last quarter, when the other half of the moon is illuminated. Before and after the new moon, there are two other cycles which are generally referred to as waning and waxing crescents.

The belt of stars or a group of stars are known as zodiac constellations. Every year the sun follows a similar path as it moves through the zodiac constellation. ${ }^{31}$ But the moon's path which is seen from the earth is not similar because the moon takes 27.3 days of each month to complete its journey through the zodiac constellations in an ascending and descending rhythm. Each ascending and descending rhythm period lasts about two weeks. Based on these ascending and descending days (Table 1), the farmer practicing biodynamic agriculture will decide the farming activities to be undertaken. In addition, the moon passes through the constellations (group of stars or 12 zodiac signs), a group of 3 constellations are grouped under 4 classical elements of nature such as fire, light /air, water and earth (Table 1). When this reflection touches the earth, it encourages the plant development. ${ }^{32}$

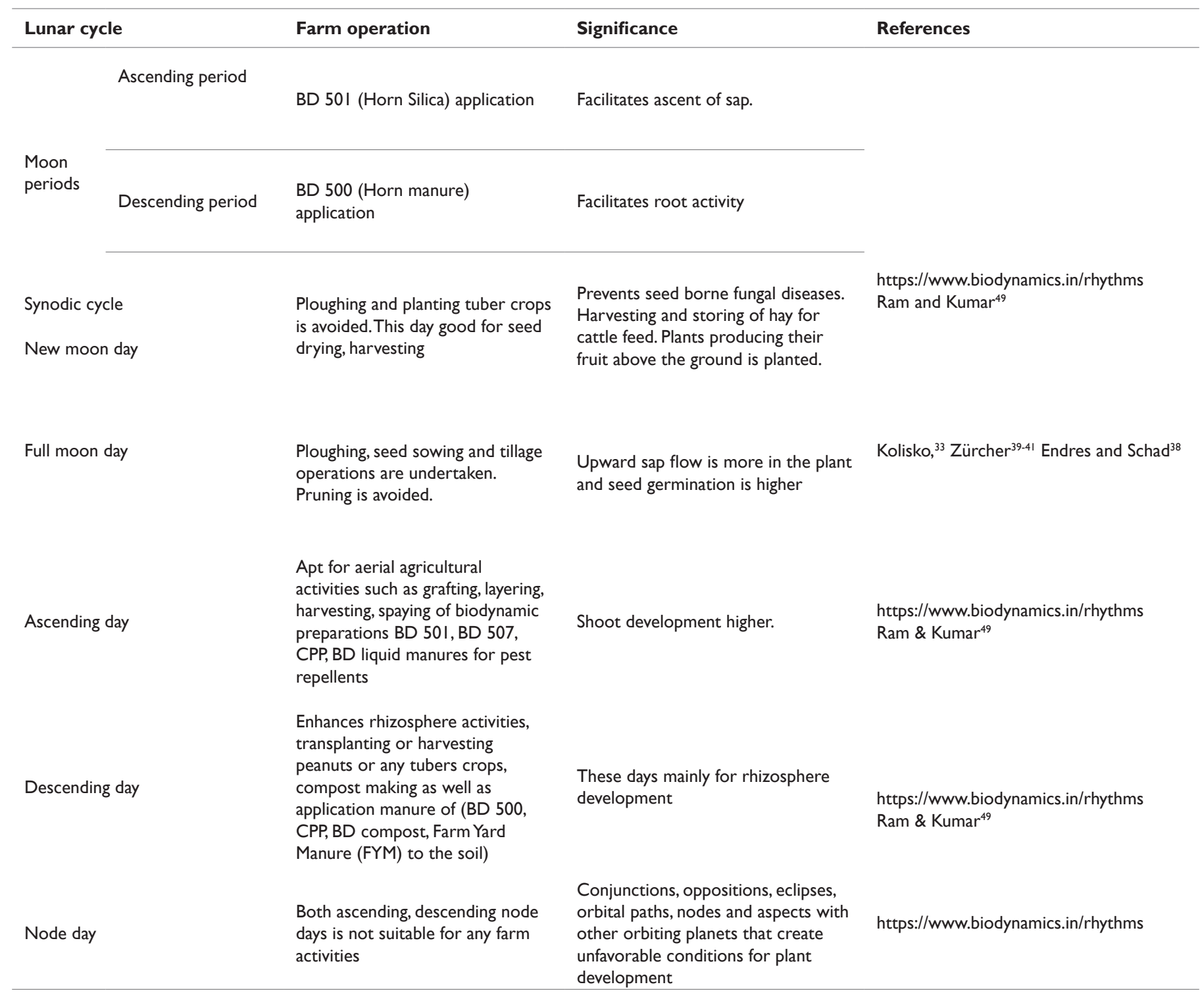


Table continued..

\begin{tabular}{|c|c|c|c|}
\hline Lunar cycle & Farm operation & Significance & References \\
\hline $\begin{array}{l}\text { Perigee } \\
\text { (Moon is closest to the Earth) }\end{array}$ & Sowing is avoided. & $\begin{array}{l}\text { Enhances fungal diseases on crops } \\
\text { and lead to crop loss and failure }\end{array}$ & \\
\hline \multirow[t]{2}{*}{$\begin{array}{l}\text { Apogee (Moon is farthest to the } \\
\text { Earth) }\end{array}$} & $\begin{array}{l}\text { Ideal time to harvesting, storage of } \\
\text { crops and for making compost. }\end{array}$ & & \\
\hline & & & Ram \& Kumar ${ }^{49}$ \\
\hline Moon opposite to Saturn & $\begin{array}{l}\text { Crop sown on the Moon opposite } \\
\text { to Saturn day strengthens the } \\
\text { plant to the extent that it can } \\
\text { resist plant disease and certain } \\
\text { insects and pests resulting in } \\
\text { lesser damage to the crop. } \\
\text { Spraying BD } 50 \text { l early in the } \\
\text { morning on crop is recommended }\end{array}$ & & $\begin{array}{l}\text { https://www.biodynamics.in/rhythms } \\
\text { Ram \& Kumar }{ }^{49}\end{array}$ \\
\hline \multicolumn{4}{|l|}{ Moon in zodiac signs } \\
\hline Fire day (Aries, Leo, Sagittarius) & Sowing seed or fruit crop & Moon is reflecting the qualities of a & \\
\hline \multicolumn{4}{|l|}{ Water day (Cancer, Scorpio, } \\
\hline Pisces) & $\begin{array}{l}\text { Sowing tuber crop, soil or land } \\
\text { preparation, weeding, harvesting. }\end{array}$ & & Thun \& Heinze ${ }^{37}$ \\
\hline \multicolumn{4}{|l|}{ Earth day (Aries, Leo, or } \\
\hline Sagittarius) & Sowing flower crop & & \\
\hline $\begin{array}{l}\text { Air day (Libra, Aquarius, or } \\
\text { Gemini) }\end{array}$ & & & \\
\hline
\end{tabular}

The moon's nearest point to the earth on this ellipse is the perigee and the furthermost point is the apogee which influences the living systems. There is one perigee and one apogee cycle every month. There are some farm activities which are encouraged or discouraged during apogee and perigee cycles. One of the hypotheses is lunar gravity which is the gravitational pull of the moon that is believed to have an impact on soil moisture content.

In the biodynamic agriculture planting calendar, when the Moon and Saturn are on opposite sides of the Earth, their respective influences are sparked into the Earth from opposite directions. The Moon's influence facilitates the calcium processes (earthly) which are connected to propagation and growth forms of plants while the Saturn forces facilitate the silica processes (cosmic) which are connected to the building up substance or bulk of the plant in root, leaf and fruit. Farmers have observed that farming activities performed during this time produce good crops because of the balancing effect of Moon and Saturn that influences the living system in the Earth.

The moon crosses the path of the sun. The crossing points are called nodes and are the only places and times where eclipses can occur. Node cycle recur approximately every 14 days, which is two nodes every month. The moon while crossing in front of the sun will negate the sun's beneficent influence for this brief period. This negative influence works into the soil being freshly cultivated at the time of the node. Therefore, BD farming do not encourage farmer to cultivate the soil, sow any seeds, transplant, prune trees or shrubs and other farm activities on the node day. The effect is like that of an eclipse of the sun by the moon.

\section{Planting through Lunar Rhythms}

As a result of Steiner's interest in scientific evidence, many earlier experiments were undertaken by $\mathrm{Kolisko}^{33}$ who found positive influence of full moon and individual constellations on seed germination as well as subsequent plant growth. Furthermore, during 1956 Maria Thun grouped 12 zodiac constellations with 4 elements (fire, water, air and earth) and differentiated various crops into 4 categories such as root, leaf, flower and fruit crops which were linked with these 4 elements. ${ }^{34}$ This is called Thun theory. ${ }^{35,36}$ Manifold trails by Thun and Heinze ${ }^{37}$ clearly demonstrated the positive effect of moon-constellation-element on sowing dates. At present, this Thun theory has been incorporated in biodynamic planting calendar and practiced by biodynamic (BD) farmers. ${ }^{34}$ The phenomenon of lunar effect on patterns of seed germination and seedling vigor has been documented by Endres \& Schad. ${ }^{38}$ In his study, it is mentioned that seed sown before the full moon resulted in improved germination. The wood science specialist Zürcher scientifically studied and found positive influence of lunar rhythms in germination of seed, growth of seedlings of various tree species, contraction and relaxation of tree trunk, ${ }^{9}$ water absorption of cell wall and chemical elements in the tissues of trees. ${ }^{39,40}$

Also, Zürcher ${ }^{41}$ reviewed numerous literatures on the lunar cycle in which he has mentioned the research work of Dr. Fritz on the development of various plant parts as an effect of moon light. Alongside, he experimented with the germination of radish which speeds up before 2 days of full moon (synodic rhythm). But, Breitler et al. ${ }^{42}$ reported the full moon light which negatively influences many genes involved in photosynthesis activity for coffee. Also, he explored that only moonlight is responsible for gene expression modification but not gravitational forces.

With respect to waxing and waning moon, Avcı and İçel, ${ }^{43}$ reported water ingredients of trees such as Cedrus libani, Populus nigra 
and Pinus brutia found higher in waxing period than waning ones and similar results found for insects' attacks for these periods. The experimental studies by Dr. Tahvare team ${ }^{44,45}$ validate the concept of seasonal as well as lunar collection of herb Ashwagandha. The Aśvagandhā root collected from full day of third month (Grīṣma Jyeștiha Paurnimāan) and fourth month of Sanskrit (Āṣậ̣ha Paurnimāā) lunar calendar to yield a superior quality of phytoconstituents than new moon. The higher content of functional groups and withanoloid respectively observed on these above months on full moon day. Thus, Aśvagandhā being a highly potent warmness drug is collected in the summer season (3rd and 4th month of the Sanskrit lunar calendar) on full moon days for better therapeutic potency. The study has shown a definite influence of lunar cycles on the growth of the plant parts assessed by root weight, pith diameter, and internodal distance that have been found to be increased on full moon days as compared to new moon days.

Some researchers found significant influence of lunar cycles on yield percentage of various cultivated crops. Kollerstrom \& Staudenmaier ${ }^{46}$ statistically explained earlier work of Ulf Abele where in the trails, an increase of average yield for about $7 \%$ in barley and oat crops was observed for the seeds sown on fire day and $21 \%$ increase in carrot and radish sown during earth day. In addition, reanalyzed data of Spiess experiments revealed that the excess yield of $7 \%$ in radish and $8 \%$ in carrot on earth day. All these trials show positive influence of Thun theory. Studies of Spiess ${ }^{47}$ on sidereal rhythms revealed highest productivity could be achieved with carrot sown three days before the full moon and at Virgo constellation, reaching up to $22 \%$ more productivity. The moon in Sagittarius observed the lowest yield for carrots. Spiess also experimented with different crops like rye, potato and bush type bean. He thus concluded that all these crops responded to the moon rhythms in a different way. Goldstein \& Barbar ${ }^{47}$ study on the influence of synodic cycle in carrot cultivation found that sowing a day before the full moon had the most positive effect, resulting in a $15 \%$ increase in productivity, but sowing during the waxing moon reduced $17 \%$ productivity. However, Mayoral et $\mathrm{al}^{48}$ specified that there are no science related textbooks or peerreviewed journal articles to claim science-based understanding for any relationship between lunar phases and plant development.

\section{Conclusion}

Many studies have concluded positive results in lunar cycle-based farming practices under scientific validation with traditional references. With these proven results under a non-monitoring environment, it is evident that biodynamic farming could benefit the farmers and consumers both quantitatively and qualitatively. With all this evidence, this farming method needs more research since farmers adopting this method are observing significant differences in soil health and quality of food. With the growing population and global impact of climate change biodynamic agriculture offers an opportunity to rediscover ancient knowledge using modern scientific tools.

\section{Acknowledgments}

None.

\section{Conflicts of interest}

Declare if any conflict of interest exists.

\section{Funding}

None.

\section{References}

1. Nabi A, Narayan S, Afroza B, et al. Biodynamic Farming in Vegetables. J Pharmacogn Phytochem. 2017;6(6):212-219.

2. vanBruggen AHC, Gamliel A, Finckh MR. Plant Disease Management in Organic Farming System. Pest Manag Sci. 2016;72(1):30-44.

3. Beeson C. The Moon and Plant Growth. Nature. 1946;158:572-573.

4. Schad W. Lunar Influence on Plants. Earth, Moon, and Planets. 1999;85:405-409.

5. Harris RJ, Summers W. RJ Harris's Moon Gardening. 2nd edn. Really Useful Books; 2002.

6. Spiess H. Lunar Rhythms in Plants. Biodynamics. 2000;229:19-22.

7. Spiess H. Chronobiological Investigations of Crops Grown under Biodynamic Management. 1. Experiments with Seeding Dates to Ascertain the Effects of Lunar Rhythms on the Growth of Winter Rye. Biol Agric Hortic. 1990a; 7:165-178.

8. Spiess H. Chronobiological Investigations of Crops Grown under Biodynamic Management II. On the Growth of Little Radish. Biol Agric Hortic. 1990b;7(2):179-189.

9. Zürcher E, Cantiani M, Sorbetti-Guerri F, et al. Tree Stem Diameters Fluctuate with Tide. Nature. 1998;392:665-666.

10. Bunning E, Moser I. Interference of Moonlight with the Photoperiodic Measurement of Time by Plants, and their Adaptive Reaction. Proceedings of the National Academy of Sciences (USA). 1969;62(4):1018-1022.

11. Kollerstrom N. Gardening and Planting by the Moon. USA: Berkshire, Quantum: 2018.

12. Hannah R. The Moon and the Planets in Classical Greece and Rome. Oxford Research Encyclopedia of Planetary Science. 2020.

13. Taverner E. The Roman Farmer and the Moon. Transactions of the American Philological Association. 1918;49:67-82.

14. Roach J. Age-Old Moon Gardening Growing in Popularity. National Geographic News. 2003.

15. Koepf HH, Pettersson BD, Schaumann W. Bio-dynamic Agriculture: Practical Applications of The Bio-dynamic Method. New York, USA: Anthroposophic Press; 1990

16. Podolinsky A. Biodynamik - Landwirtschaft der Zukunft. German: Frumenta Verlag; 2000.

17. Turinek M, Mlakar SG, Bavec $M$ and Bavec F. Biodynamic Agriculture Research Progress and Priorities. Renew. Agric. Food Syst. 2009;24():146-154.

18. Di Silvestro DR. Wheat and Low-Input Agriculture: Agronomic, Nutritional and Nutraceutical Implications. Ph.D. Thesis. Bologna: Bologna University; 2012.

19. Steiner R. Agriculture: Spiritual Foundations for the Renewal of Agriculture. New York, USA: Anthroposophic Press; 1924.

20. Koepf HH. The Biodynamic Farm. New York, USA: Anthroposophic Press; 1989.

21. Sattler F, Wistinghausen EV. Biodynamic Farming Practice. Biodynamic Agricultural Association. UK: Woodman Lane; 1992.

22. Beismann M. Landscaping on a Farm in Northern Germany, A Case Study of Conceptual and Social Fundamentals for the Development of an Ecologically Sound Agro Landscape. Agric Ecosyst Environ. 1997;63(2-3):173-184.

23. Vereijken JFHM, van Gelder T and Baars T. Nature and Landscape Development on Organic Farms. Agric Ecosyst Environ. 1997;63:201220 
24. Lampkin, N. Organic Farming. UK: Fanning Press Books; 1990.

25. Paull J. Organics Olympiad 2011: Global Indices of Leadership in Organic Agriculture. Soc Sci Dev J. 2011; 4:144-150.

26. Villanueva-Rey P, Vázquez-Rowe I, Moreira MT, et al. Comparative Life Cycle Assessment in The Wine Sector: Biodynamic Vs. Conventional Viticulture Activities in NW Spain. $J$ Clean Prod. 2014;65:330-341.

27. Demeter International. Demeter Production found the World Over: 2020

28. Koepf HH, Pettersson BB, Schaumann W. Biodynamic Agriculture Spring Valley, New York: The Anthroposophic Press; 1976.

29. Pathak RK, Ram RA. Successful Conversion of Conventional to Organic/Biodynamic:A Case Study. In: Establishing an Organic Export Sector. Production and Export of Organic Fruit and Vegetables in Asia. FAO Commodities and Trade Technical Paper. 2004. p. 61-81.

30. Spaccini R, Mazzei P, Squartini A, et al. Molecular Properties of a Fermented Manure Preparation Used as Field Spray in Biodynamic Agriculture. Environ Sci Pollut Res Int. 2012;19(9):4214-25.

31. Ellis J. Is there a role in UK Agriculture for Farming by the Cycles of the Moon? A Nuffield Farming Scholarships Report. 2010

32. Weaver D. Planting by the Moon. The Voice of Eco-Agriculture. Acres, 2019; (571):U.S.A. Magazine.

33. Kolisko E. The Moon and the Growth of Plants. Gloucester, U.K Stroud; 1936.

34. Kollerstrom N, Staudenmaier G. Evidence for Lunar-Sidereal Rhythms in Crop Yield: A Review. Biol Agric Hortic. 2001;19:247-259.

35. Thun M. Work on the Land and the Constellations. Launceston, U.K. Lanthorne Press; 1991.

36. Thun M. Gardening for Life - The Biodynamic Way. Hawthorne Press Stroud, U.K. 1999. p. 128.

37. Thun M, Heinze H. Lunar Rhythms in Sidereal Circulation and Plan Growth: Experimental Elaboration of Legal Effects in the Trigon Rhythm on Plant Growth (Mondrhythmen im Sidetischen Umlauf und Pflanzenwachstum). Germany: Darmstadt; 1979.
38. Endres KP, Schad W. Moon Rhythms in Nature. How Lunar Cycles Affect Living Organisms. Edinburgh, UK: Floris Books, 2002. p. 219 275

39. Zürcher E, Schlaepfer R, Conedera M. Looking for Differences in Wood Properties as a Function of the Felling Date: Lunar Phase-Correlated Variations in the Drying Behavior of Norway Spruce (Picea abies Karst.) and Sweet Chestnut (Castanea sativa Mill.). Trees. 2010;24:31-41.

40. Zürcher E. Water in Trees - An Essay on Astonishing Processes, Structures and Periodicities. Substantia. 2019;3:71-83.

41. Zürcher E. Plants and the Moon - Traditions and Phenomena. American Botanical Council. HerbalEGram. 2011;8(4).

42. Breitler J, Djerrab D, Leran S. Toniutti L, Guittin C, Severac D, Pratlong M, Dereeper A, Etienne H and Bertrand B. Full Moonlight-Induced Circadian Clock Entrainment in Coffea arabica. BMC Plant Biol. $2020 ; 20$.

43. Avcı M, İçel B. Effect of the Lunar Cycle on the Insect Infestation in Wood and Water Content in Trees. Turk J Agric For. 2016;17:20-29.

44. Tavhare SD, Nishteswar K, Shukla VJ. Effect of Seasonal Variations on the Phytoconstituents of Aśvagandhā W.R. to Lunar Cycles. Ancient Sci Life. 2016;35(3):150-158.

45. Tavhare SD, Nishteswar K, Shukla VJ. Influence of Lunar Cycles on Growth of Ashwagandha (Withania somnifera [L.] Dunal). Ayurveda. $2015 ; 36(30: 258-264$.

46. Kollerstrom N, Staudenmaier G. Moon trine effect: a statistical evaluation. Living Earth. 1998. p. 478-483.

47. Goldstein W and Barber B. The Effects of Planting Dates and Lunar Positions on the Yield of Carrots. Biodynamics. 2000

48. Mayoral O, Solbes J, Cantó J and Pina T. What has been Thought and Taught on the Lunar Influence on Plants in Agriculture? Perspective from Physics and Biology. Agronomy. 2020;10:955.

49. Ram R A, Kumar, A. Biodynamic Agriculture: An Advance Stage of Organic Farming. Journal of Eco-friendly Agriculture. 2019;14(1):34 37. 